\title{
MEDIEVAL NAME AND ETHNICITY: SERBS AND VLACHS
}

\author{
ŞTEFAN STAREȚU
}

\begin{abstract}
In this paper I show that in the medieval period, a strong aristocracy with elements connected to Serb identity, existed in north-eastern Hungary. We can say that this comes from an ancient symbiosis. The great noble families of Maramuresh have in common an orthodox identity, which shows traces of links with the Serbian church and the Serbian aristocracy. This is in contrast with the image of the peasant class of the Vlachs, and shows that this migration of the Vlachs from south to north probably was generated by the coming into Hungary of noble elements from Serbia, in the context of Stefan Vladislav and his influence in Hungarian politics in the XIII-XIVth century. Maramuresh is the strongest region of orthodox nobility in Hungary, and in this study I show elements spending a wide chronological range that are clues and remnants of the Balkan past, identity and connections of this region and it's elites. The social and ethnical processes in the region are determined in the wider context of connections between Serbia and Hungary, and the presence of the Serbian orthodox chur$\mathrm{ch}$ in the region as the church of the elites. The catholic establishment of Hungary accepted this autonomy, and this ecclesiastical independence, and integrated the orthodox elites, many families forming family ties with high Hungarian nobility, and thus bringing a dual identity to the region. This is shows in the social contrasts, of orthodox branches becoming rustic, and living in villages with other nobles who became impoverished, and of the magyarised branches, who remained in the high aristocracy to the end.
\end{abstract}

Stefan Starețu, PhD student, University of Bucharest, Faculty of History, B-dul Regina Elisabeta 4-12, sector 5, cod 030018, Bucureşti, Romania, e-mail: istaretu@yahoo.com

Keywords: Serbs, Vlachs, Serbian church, ethnicity, Wallachia, Moldavia.

DOI: http://dx.doi.org/10.14746/bp.2015.22.7

In the medieval period, there was a tendency of calling the Serbs "Vlachs". We can say that this comes from an ancient symbiosis.

What is less known is that the Serbs themselves accepted this terminology. As we can see from the Ballad of Milos Obilici, where the Serb heroes are called Vlachs ${ }^{1}$, without a pejorative sense. All the Serb population from Bosnia was called Vlach, and here we can add the strange similarity between the ancient name of Serbs from Bosnia, Mavrovlahos, and the name of Moldavia, Mavrovlahia, or of Maramures. Mostly the Serbs of Montenegro are called Vlachs in Dubrovnik documents ${ }^{2}$.

A least known fact is that after the refuge of Arsenije Cernojevic, the Serbs were issued a Diploma by Rudolf II called the Vlachs Diploma ${ }^{3}$. The heraldry depicted for these "Vlachs" is consisted of the Serbs coat of arms from Nemanjic Serbia.

${ }^{1}$ Anton Balota, Izvoarele Baladei Populare Româneşti [Sources Romanian folk ballads], (Bucureşti: Ed. Saeculum I.O., 2005), 34.

2 Bosko I. Bojovic, Raguse et L'Impire Ottoman (1430-1520) [Ragusa and The Ottoman Empire (1430-1520)], (Paris: Association Pierre Belon, 1998), 53.

3 Dragomir M. Acovic, Heraldika i Srbi [Heraldica and Serbs],(Beograd: Zavod za Utbenike,2012), 556. 
It represents the Serb patriarch receiving the diploma from Leopold. This associates the dual ideology of empire and patriarch, with the heraldic coat of arms of the Holy Nemanjic dynasty, and with the vlachethnonym.

For example we can see this text from the ballad of Milosh Obilici:

TSAR MURAD sat beneath his tent with the pashas of his power

And his viziers, and counsel took what way to smite the Giaour

And win with least disaster; when lo there came from afar

The vizier Osman running to claim reward of the tsar.

He kissed the hand and the garment, himself to the earth he bowed,

And thus to Murad, the Turkish tsar, the vizier spake aloud:

"Murad, the Sun of all the East, holy Mahomet's heir!

Rejoice! the Servian Empire thou hast conquered everywhere!

Here come three Servian voývodas that have chiefly made us fear;

They come hither to surrender, for down have they turned the spear."

It pleased the Sultan Murad; it was pleasant in his ears;

Woes plagued him not. He spake unto the pashas and viziers:

"Brave pashas, glorious viziers, my captains of command,

Shall I reach to the Wallachians my foot or my white hand?"

and

Said the viziers: "O glorious lord, put not thy hand to shame;

Shame were it to reach out to one of the Wallachian name!

Stretch out thy foot unto them, and let them kiss it sweet,

And let them be forever at all times 'neath thy feet."

Outspake Vizier Ushtúgliya: "Tsar Murad, our crown of gold, shall we go out before them?" Then answered Murad the bold:

"Go out to the field before them, and three great cloths unfold;

Stretch one of red, the second of white, the third green glorious.

When the slaves drive on their horses, if they come to fight with us,

All three of the cloths beneath their feet will they trample under here.

If they bring me the keys of the cities and the taxes for seven year,

On the red cloth will they trample, the red and the white beside,

But the green will they lift on their lances and thereunder will they ride."

When the tsar's troopers heard it, before the three they flew ${ }^{4}$.

All Serbs in Bosnia and Krajina (how many of them are left) are called pejoratively not Vlachs by their neighbours. The question is, was there a bilingualism in the Serbian medieval state and a common identity. The reproduction of the Romanian names in the Zica charter so precisely phonetic shows that maybe the author of the chrysobull ${ }^{5}$ or the one who wrote it spoke also Romanian, otherwise the names would have been Slavonised. It is clear that Stari Raska comes from Stari Vlaska, with a rothacism, and Raska from Vlaska (this is exemplified by the double name of Banat, as Vlaska or Raska).

4 "Haw Milosh Obilich Slew the Sultan Murad", Sacred-Texts Legends \& Sagas Index Previous Next, http://sacred-texts.com/neu/hbs/hbs13.htm.

${ }^{5}$ Silviu Dragomir, Vlahii din nordul Peninsulei Balcanice in Evul Mediu [Vlachs of the northern Balkans in the Middle Ages], (Bucureşti:Ed. Academiei Republicii Populare Române, 1959), 231. 
Is this a similar fact to the Vlach denomination of the Sarakachiani, or other pastoral people (who are most probably of Romanian origin, because the Albanians, although pastoral, have never been called Vlachs), or this shows a common ethno genesis, symbiosis and bilingualism between Serbs and Vlachs? I personally believe that the Vlach ethno genesis is linked to the medieval Serbs state and its influence in Hungary and the double naming of Serbs is linked to an ancient Slavo-Latin unity in former Dacia and Illyria (mostly Illyria).

The Serbs and Vlachs are probably a single ethnic substance, constructed in the Balkan Peninsula as a unity in the $8^{\text {th }}-14^{\text {th }}$ century. When the Balkan element spread into Hungary, all the way to Hallych and Maramuresh, it was crystalized as a Serb identity element, with a Serbian church and a Serbian political ideology.

All the names of the Vlachs known in Hungarian documents have a Serb resonance ${ }^{6}$. We can see these names compared with the Serbian names in Silviu Dragomir's work $^{7}$.

The first bishop of Moldavia was named Servoepiskopos, a fact which is important for the documentation of the Serbian allegiance of the Moldavian church. Moldavia herself was called Mavrovlahia, a term that designates the Serbs of Bosnia.

The pastoral militias which were bilingual and who consolidated the orthodox continuity and state persistence in Illyria during the middle ages are the basis of the Vlach law, which stands identically in medieval Serbia, with the quinquagesima, and in Hungary and in Poland, which shows that the nobles that came northward came with the practice specific from Serbia.

The Wallachian name for the Serbs is alternate Serb and Vlach. The name of the Maramuresh noble village of $\mathrm{Sarbi}^{8}$, inhabited by the great families of Berinde ${ }^{9}$, Bud $^{10}$, Feier ${ }^{11}$ and Tiplea ${ }^{12}$, descended from Locovoj ${ }^{13} \mathrm{knez}_{\text {of Cosau }}{ }^{14}$, is called Olahtotfalu, and Cosau comes from Kosovo. The naming of one of the most important villages from Maramuresh Olahotfalva in Hungarian and Sarbi in Romanian shows the mutual synonymy of the terms in medieval mentality, and the reference to KosauKosov is important. It is important to know that the Berinde family of Cosau is re-

${ }^{6}$ Ioan Aurel Pop, Din mâinile valahilor schismatici [From the hands of schismatics Vlachs], (Bucureşti: Ed. Litera, 2011), 23, 41, 65.

7 Dragomir, Vlahii din nordul Peninsulei Balcanice, 142.

8 Thaler Tamas, Zsidi Vilmos, Karpatalja [Karpatalja], (Debrecen:Ed. Anno, 2007), pg. 64.

${ }^{9}$ Alexandru Filipaşcu, Enciclopedia familiilor nobile maramureşene de origine română [Encyclopedia noble families Maramures Romanian origin],(Cluj Napoca: Ed. Dacia, 2006), 23.

${ }^{10}$ Filipaşcu, Enciclopedia familiilor nobile maramureşene, 39.

11 Ibid., 92.

12 Ibid., 92.

13 Joody Pal, Cercetarea calității de nobil în comitatul Maramureş - Anii 1749-1769, Ed. a II-a [Research noble quality in Maramures County - Years 1749-1769, Ed. II],(Cluj Napoca: Ed. Societăţii culturale Pro Maramureş “Dragoş Vodă”, 2003), 56.

${ }^{14}$ Ioan Cav. de Puşcariu, Date istorice privitoare la familiile nobile române, Ed. a II-a [Historical data regarding the Romanian noble families, Ed. II],(Cluj Napoca: Ed. Societății culturale Pro Maramureş "Dragoş Vodă", 2003), 8. 
lated to the royal family of Moldavia, Mathias Corvin wanting to put a Berinde from Sarbi ${ }^{15}$, Maramuresh, and voivode in Moldavia.

In the village the Sarbi of Maramures lives the Birtoc family, which is a descendant from the brother of Bogdan, founder of Moldavia, Iuga, by Ioan, who had as sonin-law Mihail Gerhes, ancestor of the villagers from Sarbi ${ }^{16}$. This links the village of Sarbi to the founding family of Moldavia. Other families descending from Bogdan are the Petrovai and Giurgi from Petrova, Barsana and Poienile Izei. In Barsana lives the Petrovai family, thus linking Barsana also to the founding family of Moldavia. We shall see how important these two villages will be in our research.

All voivode churches in Moldova and Maramuresh and Wallachia have the representation of Simeon and Sava ${ }^{17}$ in the churches, alongside the Jesse tree, a sign of ideological identification with the holy Serb monarchy and the choosing of the heavenly kingdom by Lazar. In the altar of the church of Ieud, Saint Stefan Decanski is represented alongside Saint Nicholas, which is reference to the wonder noted in his hagiography.

Statuta Valachorum (English: Vlach Statute, Serbian: Vlaškizakon) was the name for a number of laws (statutes) enacted in the 17th century both by the king of the Habsburg Monarchy as well as the Croatian Parliament (Sabor), whose purpose was to define rules on the taxation and tenancy rights of Vlachs on the Military Frontier

In 1608, Austrian emperor Rudolf II instituted such a law, under which the Vlachs of the Military Frontier, regardless of their faith, owed one tenth of their income to the Bishop of Zagreb, and 1/9th to the feudal lords whose land they occupied. In 1627, Emperor Ferdinand II passed a decree allowing the Frontier Vlachs land use regardless of the land's ownership, in an effort to make the Grenzer independent from the Croatian nobility, and more willing to wage wars for him. In 1629, Sabor also passed such a law in order to subdue the Vlachs who were revolting and were refusing to pay taxes to the Croatian gentry ${ }^{18}$, blackmailing them by threatening to enter into an alliance with the Ottomans, at that time tolerant to the Orthodox Church. By persuasion of the military command of the Croatian Military Frontier and Serbian Orthodox Church, Vlachs refused that law and they demanded confirmation of royal benefits from 1627. In 1630, despite the decision made by Sabor, Ferdinand II had enacted Statuta Valachorum according to which Vlachs would freely settle in the military areas of Križevci, Koprivnica and Ivanec and keep privileges they had in the Ottoman Empire. Territorialization of the area which was under Varaždin Generalat, respec-

15 Ştefan S. Gorovei, Maria Magdalena Szekely, Princeps omni laude major-O istorie a lui Ştefan cel Mare [Prince all major praise- A History of Stephen the Great], (Sfănta Mănăstire Putna, Ed. Muşatinii, 2005), 69.

${ }^{16}$ Filipaşcu, Enciclopedia familiilor nobile maramureşene, 28-29.

17 Carmen Laura Dumitrescu, Pictura murală din Țara Românească în veacul al XVI-lea [Mural painting of the Romanian Land the sixteenth century], (Bucureşti: Ed. Meridiane, 1978), 48.

18 Fedor Moacanin, "Statuta valachorum od 14 aprila 1667 [Statute Valachorum of 14 April 1667]", Historijski Zbornik 15(1976-77): 225-232, http://www.historiografija.hr/hz/1976/HZ_29-30_21_ MOACANIN.pdf. 
tively Slavonian Military Frontier i.e. formation of a delineation was also included in Statuta Valachorum. Until then, Varaždin Generalat had not been delimited.

The 1630 Statuta Valachorum applied only to Vlachs in the area of Varaždin Generalat, located between Drava and Sava, but later, all Vlachs used that statute. The goal of Statuta Valachorum was to bring the Vlachs under supervision of the imperial court, giving them an appearance of autonomy, despite the fact that the level of selfgovernment they had before them was actually decreased. Ferdinand II did not include matters of land ownership in the statute, so that he would not upset the Croatian nobility when Ferdinand III came to power, the ownership of the Croatian Military Frontier land was transferred to the imperial court, without an actual legal basis.- In the 18th century, the nobility was finally formally deprived of all Frontier land when it was declared an imperial fief. This law was in fact a harsh law on the Vlachs, because it cancelled their ancient nobility of free people of pastoral militias from the Balkans.

The iconographical representation of the Statuta Valahorum is important as we have seen. This strong association of symbolist is an important factor in the self-defining of Serbs as Vlachs, with all their monarchical ideology. We can say that the knowledge of both a Slavic language and Romanian by all Serbs in medieval Serbia is confirmed by the correct phonetic translation of the names in the charter of Zica ${ }^{19}$, and not the Slavic translation of them, names given by landowners of the Romanian language to serfs.

The term Vlachs in the charters is a synonym for Serb, and has not the pastoral connotation attributed to it. The term Albanian is clearly differentiated from the SerbVlach identity ${ }^{20}$. In Wallachia, the same name of Vlach is given to serfs, in both the term Vlach or "Ruman". ${ }^{21}$ This is in the same sense saying that the peasants are human in a general sense. The Vlach form appears in documents from Stefan the Great to the Buzau boyars ${ }^{22}$, and also in a document regarding transactions in Siret between Armenian merchants and Vlach boyars. Dubrovnik calls Serbs in Montenegro Vlachs only during the Middle Ages. The essential problem is that the Serbo-Vlachs or Maurovlachs emigrated from Maramuresh, Ung and Bereg, which were old Romanian regions from $14^{\text {th }}$ century Hungary.

They emigrated to the former Kievian Russ, Poland or today's Slovakia, retained their orthodox faith and their ecclesiastical allegiance to the Serbian patriarchate in Pecs, which was activated in the Hungarian Kingdom under Hunyadi Janos and Mathias $^{23}$. This was all because of and under the patronage of Maxim Brankovic, who

\footnotetext{
${ }^{19}$ Franciscus Miklosich, Monumenta Serbica spectantia historiam Serbiae, Bosnae, Ragusii [Serbian monuments pertaining to the history of Serbia, Bosnia, Ragusa], (Viennae: Braumuller, 1858), 11-12.

20 Ibid. 11-12.

${ }^{21}$ Constantin C. Giurescu, Studii de istorie socială. Vechimea Romîniei. Despre rumîni. Despre boieri [Studies of social history. Rominiei age. About rumen. About boyars], (Bucureşti: Ed. Universul, 1943), 139.

22 Giurescu, Studii de istorie socială. Vechimea Romîniei, 139.

23 Svetlana Tomin, Vladika Maxim Brankovic [Bishop Maxim Brankovic], (Novi Sad: University Novi Sad Press, 2011), 43.
} 
was married to the king's wife's sister before taking his monastic vows ${ }^{24}$. This was until the re-foundation of the Pecs patriarchate under Makarije Sokolovic with support from the Valachian and Moldavian voivodes Vlad Vintila, related to Serbs ${ }^{25}$, and Petru Rares (whose wife Ecatherine Brankovic had a nephew of the great Maxim Brankovic mentioned above).

Petru Raresh speaks of Serbia as his country. The common linguistic aspect of this Serbo-Vlach unity was lost in my opinion in the $17^{\text {th }}-18^{\text {th }}$ centuries, when this old Vlach commonwealth was lost. Serbians which were under the influence of the military frontier started speaking Croatian (the absence of the dialectal difference between Croatian and Serbian is significant, and shows the influence), which led to the disappearance of the Romanian Serb dialect. The nobles of Maramuresh and Bukovina became Russian speakers ${ }^{26}$, and formed the basic background of the Russia of today.

This was done by the decision of the Ukrainian Greek-Catholic priests ${ }^{27}$, and in Bukovina by the influence of the Ukrainian serfs brought by the boyars to their estates $^{28}$. The problem was that after the $18^{\text {th }}$ century, all of the Vlach-Serb commonwealth passed through a period of rustication, and so the Montenegrin knez-prince, the Vlach "mosneni" and the Moldavian "razesi" were born. In this process, which is similar also in the Szekely Land ${ }^{29}$, many nobles lost their original language and passed over to the language of their serfs.

In Maramuresh (Ung, Bereg, and Ugocsa) and Moldavia, the northernmost part of the Vlach nobility, this process led to the Ucrainianisation of this nobility. So, great families such as Risko of Dragovo ${ }^{30}$, Uglyay ${ }^{31}$, Bogdan de Uglea ${ }^{32}$, Roman $^{33}$, Lipchey ${ }^{34}$, Crichfalulsy ${ }^{35}$, Stojka and Pop of Crishanesh or Dragovo, Bedej (Bedeoan) of Bedevlija ${ }^{36}$, which have ancestries documented from 1375 as great nobles of Maramuresh, became linguistically Ukrainian and by peasant occupation. This meant the end of the old military nomadism, and the end of linguistically unified space. Interestingly that after the annexation of Maramuresh from Romania (between 1918 and 1919 (to Czechoslovakia, Saint Justin Popovich of the Serbian orthodox

\footnotetext{
${ }^{24}$ Ibid., 43.

${ }^{25}$ Maria Magdalena Szekely, Sfetnicii lui Petru Rareş [Counselors Petru Rares], (Iaşi: Ed. Universității Alexandru Ioan Cuza, 2007), 54.

${ }^{26}$ Nuțu Rosca, Mănăstirea Bârsana [Barsana Monastery], (Sighetul Marmației: Ed. Arhiepiscopiei Maramureşului şi Sătmarului, 2011),11.

27 Rosca, Mănăstirea Bârsana, 23.

${ }^{28}$ Ion Nistor, Românii din nordul Bucovinei [Romanians in Northern Bukovina], (Bucureşti: Ed. Academiei Române, 1923), 34.

29 Jozsef Palmay, Haromszek Varmegye Nemes Csaladjai, Vol. I [Enter Háromszék County noble family, Vol. I], (Sepsi-Szent-Gyorgy: 1901, reeditare, Ed. Charta, 2000), 24.

${ }^{30}$ Filipaşcu, Enciclopedia familiilor nobile maramureșene, 268.

${ }^{31} \mathrm{Pal}$, Cercetarea calității de nobil în comitatul Maramureș, 14-15.

${ }^{32}$ Filipaşcu, Enciclopedia familiilor nobile maramureșene, 232.

33 Ibid., 232.

${ }^{34}$ Ibid., 154.

${ }^{35}$ Ibid., 18.

${ }^{36}$ Cav. de Puşcariu, Date istorice privitoare la familiile nobile române, 6.
} 
church made evangelical trips to Zakarpatija to reconvert to Balkan orthodoxy those Ruthenian Greek-Catholic lands of old Serb origin.

The same Ukrainian Greek-Catholic fanatical clergy tried to impose unionism also in Serbia. They made missions from Maramuresh to Moraca, in Serbia ${ }^{37}$, and in Moraca succeeded in imposing a sort of union, but they were opposed by the metropolitan Peter Moghyla, of Moldavian princely origin, who was related to the Maramuresh nobility, and by his allies Mathej Basarab of Wallachia and Vasile Lupu of Moldova ${ }^{38}$. This gave the possibility of the gaining of immunity by the Serb Orthodox Church, which included also the remaining orthodox of Transylvania, after the forced catholicization of Athanasie Anghel ${ }^{39}$. The new titles of some bishops of this ecclesiastical corpus, like the bishop of Arad, who was called a Serbo-Romanian bishop ${ }^{40}$, shows the last glow of this spiritual unity. The possibility of missionaries of great figures of orthodoxy like Visarion Saray into Transylvania, which followed the activity of the great humanist Brankovics Gyorgy, bilingual, and adept of the unity between the two peoples is relevant.

Brankovics Gyorgy had a great role in the genealogical conscience of the nobility of Wallachia and Moldavia, which extracted its family founders from the poems and heroes of Vidovdan, Brankovich for Brancoveanu ${ }^{41}$, Balsic for Bals ${ }^{42}$, Obilici (Topolici $^{43}$, for Topliceanu, and the Smederevo Cantacuzenes for the Cantacuzino. All this Serb conscience of nobility is conserved in the work of Matei Cantacuzino about genealogies ${ }^{44}$. The sense of Vlach in the Middle Ages must not be confined to the peasant sense. The peasant, being pastoral, nomad or agricultural, had an ethnic denomination which is linked to the idea of being a servile imitation of a noble.

Maramuresh has a great number of noble families. These families are all referred to in their nobility charters as "Vlachs" 45 . The sense of Vlachs in these charters is not linked to the sense of Vlachs tied to the peasant "jus valachicum". No Maramuresh village ever paid taxes according to Jus Valachicum. The boyars of Maramuresh were all recognized as nobles. The protest of the Putna monastery against the forcible catholicization of the Moisei monastery says it was built by Maramuresh boyars ${ }^{46}$, who

${ }^{37}$ Ionel Cândea, Paul Cernovodeanu, and Gheorghe Lazăr, Inchinare lui Petre Ş. Năsturel la 80 de ani [Worship Petre S. Nasturel in 80 years], (Brăila: Ed. Istros, 2003), 180.

38 Ibid., 183.

39 Vasile Mărculet, Uniatism in vremea lui Brâncoveanu [Uniatism in his time Brancovan], în curs de publicare.

${ }^{40}$ Monahismul orthodox Românesc, vol. I [Romanian Orthodox Monasticism, vol. I], (Bucureşti: Ed. Basilica, 2014), 515.

${ }^{41}$ Mihail Cantacuzino, Genealogia Cantacuzinilor [Genealogy Cantacuzino], (Bucureşti: Ed. Minerva, 1902), 26,406.

42 Mihai Dim. Sturdza, Familiile boiereşti din Moldova şi Țara Românească, vol.I [Noble families in Moldova and the Romanian Country, vol. I], (Bucureşti, Ed. Simetria, 2011), 231.

${ }^{43}$ Cantacuzino, Genealogia Cantacuzinilor, 170.

44 Ibid. 170.

${ }^{45}$ Filipaşcu, Enciclopedia familiilor nobile maramureşene, 19.

${ }^{46}$ Nuțu Roşca, Mănăstirea Moisei[Monastery Moisei], (Sighetul Marmației: Ed. Arhiepiscopia Maramureşului şi Sătmarului, 2012), 53. 
now have ruralized descendants. The Candea family of nobles related to the Corvins gave the royal city of Hateg two oxen ${ }^{47}$, this not being a Jus Valachicum custom. For example, the Dragomir family of Dragomiresti descends from a Dragomer olaho ${ }^{48}$. The Dragos family from Bedeu descended from their ancestors Dragh and Dragus Volahorum and serviencium ipsius Domini Nostri Regis ${ }^{49}$. The Dragffy family appears with the same record as the Zaas olahu family ${ }^{50}$. This shows that Serb and Vlach can intermix in senses. In the case of the Berinde family from Budesti, Locovoi the ancestor appears as "filiorum Locovoi fidelium olachorum nostrarorum ${ }^{51}$. But this sense is not the pastoral nomad sense, but the noble sense. For example, if we analyse the charter given by Charles Robert of Anjou for Staniszlo Berszan, the senior of the Varalja (Barsana) lordship, we can find that the area known as Stramtura is donated to him as a place for him to put his serfs.

The serfs exist to this day, in the village of Stramtura, which is separated from Barsana, a village inhabited by the descendants of Staniszlo Berszan by a river, and the serfs were completely separated socially. No mixed weddings, no possibility for the serfs from Stramtura to live in the village of the boyars, although the nobles and their serfs look the same, because of the process of ruralisation from the $18^{\text {th }}$ century of the Maramuresh nobility.

If the nobles of Maramuresh were descended from a pastoral population, this sort of social separation, which is attested by the charter of the Angevins, but which had existed before coming to Maramuresh, would not have existed, and some serfs from Stramtura $^{52}$ would have been given nobility status. But this is not the case. Only the descendants of Staniszlo Berszan and his allied families, the Petrovai family descended from the Tatomir voivode of Bereg ${ }^{53}$, remained as nobles, and no intermarrying with the serfs of Stramtura is attested to this day.

This shows that the social separation existed before the Hungarian period, from Serbia, and the term Sarbi was used as a parallel for the term Olah in the name of the above mentioned Maramuresh village, which has also a village of serfs on its border, the village of Hoteni, inhabited by the Hoteanu peasant serf family, and which as in the case of Barsana, has no intermixing attested to this day. The village Sarbi is situated in the Cosau (Kosov etymology the Kosovo field) valley, in the Cosau possessions of Lokovoj of Kosau (Kosov). The Serb name of both the land (river) and noble shows a correlation.

\footnotetext{
${ }^{47}$ Radu Popa, La începuturile evului mediu românesc. Țara Hațegului [In the early Middle Ages Romanian. Hațeg Country],(Bucureşti: Ed. Ştiinţifică şi Enciclopedică, 1988), 98.

48 Ioan Mihaly de Apsa, Diplome maramureşene din secolul al XIV-lea şi al XV-lea [ Maramures Diplomas century XIV and XV], (Sighetul Marmației: Tipografia Mayer şi Berger, 1900),60.

49 Mihaly de Apsa, Diplome maramureşene din secolul al XIV-lea, 13.

50 Ibid. 82.

51 Ibid. 50.

52 Roşca, Mănăstirea Moisei, 25.

53 Pal, Cercetarea calității de nobil în comitatul Maramureş, 169.
} 
The same is with the village of Cuhea, inhabited by the descendants of the Gherhes of Sarasau ${ }^{54}$, which has its serf village of Bocicoel, the village of Sapanta, which has its serf village of Teceul Mic, and with the nobles of Sieu, which have the serfs of Botiza and Rozavlea.

When a peasant from Rozavlea wanted in the $17^{\text {th }}$ century to take the name Petrovai, usurping the noble Petrovai family of Petrova and Barsana ${ }^{55}$, the authorities forced the serfs to take the name Petruvan, as to totally separate them from the true nobles. And when Atanasie Rednic usurped the name of Rednic ${ }^{56}$ to make uniate propaganda the nobles of Giulesti, although rusticied opposed him and also one of his relatives who wanted to become a vice-comis of Maramuresh, deposed him and proved him as a fraud.

Such a conscience was combined with the veneration of Saints Simeon and Sava by the nobility, and the noble villages, and their absence in the villages of the serfs, and the total separation of the nobles from the peasants. Although their similar appearance and way of life after the $17^{\text {th }}$ century shows that a separation existed before the $14^{\text {th }}$ century, and this separation can be traced back to the social and ethnic structure of medieval Serbia, with the stating of the Serbian medieval law regarding the rules of interaction between Serbs and peasants. For me, this shows that the Maramuresh nobles, when coming to this area had brought with them serfs and the serfs remained serfs perpetually, having no possibility of becoming nobility. This shows that the idea of giving nobility to some more influent knezes-princes and leaders of the Vlachs in the Hungarian kingdom by the royalty for military merits and fidelity is an error. This nobility is more ancient than the moving of Hungary, and it was a fact before and after the coming to Hungary remained a fact, as was the servitude of the servants of these nobles.

The only place where this separation could have taken place is in Serb society, and its precursors, when a strong social structure similar to the Carolingian social structure with the relationships between franks and Galo-Romans being strictly regulated, as in Norman England later, and this structure was brought to Hungary, and has been kept to this day.

It may not be a coincidence that till the $14^{\text {th }}$ century, the great boyar family of the Filipescu were considered to have a Serbo-Slavic identity ${ }^{57}$, and were as such filo Russian in politics, as was the family of the wife of Constantine Brancoveanu, with old Moldavian and possibly Maramuresh origins ${ }^{58}$. This nobility is a totally separate fact to the Vlach law, and the denomination of Olah that appears in Hungarian doc-

${ }^{54}$ Ibid. 23.

${ }^{55}$ Filipaşcu, Enciclopedia familiilor nobile maramureşene, 198.

56 Ibid., 371.

${ }^{57}$ Neagu Djuvara, Thocomerius-Negru Vodă, ed. a III-a [Thocomerius-Negru Voda, ed. III], (Bucureşti: Ed. Humanitas, 2011), 13.

58 Ştefan Starețu, Neamul Doamnei Maria Brâncoveanu [Nation Lady Maria Brancovan], (Râmnicu Vâlcea: Revista on-line Art-Emis, 19.04.2014-www.art-emis.ro/istorie/2227-neamul-doamnei-mariabrancoveanu.html). 
uments regarding the nobility of some Maramuresh boyars has an explanation in the following.

Hungary was at war with the Serbian Dushan. Many Maramuresh nobles cooperated with Dushan, as can be seen in the monetary treasures found at Cuhea which shows the financial cooperation between Dushan and Bogdan in the founding of Moldavia as an independent orthodox state, so the naming of the nobles with the name Olah in the documents was a tentative way of separating them from the country of origin, as was with the Ruthenians of Ukraine, which were called Vlachs in Polish documents exactly during the aggressions between Poland and the Russian magnates of Lithuania or with Moscow Russia, also in the same direction.

The Olah nation was a paravane, a tentative way to separate an orthodox people from spaces which supported its tentative move towards freedom. The solid nobility of the Sas Herb from Poland, a branch of the Dragffy, which inhabited compact villages in the Halicz area of Poland, around the Drohobycz or Stryi areas, is another proof of this noble conscience.

The villages which are inhabited entirely by descendants of the Sas Herb are completely isolated genealogically from the other orthodox Russians from the area or from the Poles, the same case being found in Maramuresh with the Ukrainian minority.

In the cases of the villages from the Uglea area, where the nobles were linguistically assimilated to the Russophone population, the isolation remained, and the marriages were made with the Roumanophone population from the other noble's villages from the Apsa region or from the Iza of the Cosau valley. We find Bedeoanu family in Giulesti ${ }^{59}$ or Lipcei family in Rona ${ }^{60}$, although the main branches of these families are today Russophone in Transcarpatia. Even in the case of returning families of noble Romanian origin from Poland, of the Sas Herb, like the Ilnitski ${ }^{61}$ or Dragomerictki families, the members settled in villages inhabited by the noble's roumanophone, and not by Ukrainians, like in Barsana. There are also branches of the Sas Herb who after the incorporation of Bukovina in Halycz, emigrated there for the preservation of the orthodox faith. Although Russophone, they married into the Romanian nobles families of Moldavia, succeeding in the Ruthenization of some of them, like the intermarriage of the Dobrovolski ${ }^{62}$ family of Sas Herb with the Teutu, but kept separate from the Ukrainian peasants.

The Maramuresh also adopted religious separation. When after 1700 the GreekCatholic Uniatism was imposed in the Ukrainian speaking areas and in Transylvania, Maramuresh remained an enclave in the Carpathians and succeeded in becoming part of the Serb Karlowitz Patriarchate, and bishops of the Serbian Church are mentioned in the churches of the nobles of Maramuresh who painted with their world

\footnotetext{
${ }^{59}$ Filipaşcu, Enciclopedia familiilor nobile maramureşene, 19.

${ }^{60}$ Ibid., 153.

${ }^{61}$ Ibid., 130.

${ }^{62}$ Teodor Bălan, Documente bucovinene [Documents Bucovina],(Cernăuți: Ed. Mitropoliei Bucovinei, 1939), 56.
} 
famous painting just at that period, as founders of the painting, such as in Ieud or Budesti ${ }^{63}$.

Also in some iconographic programs, Russian orthodox themes appear, such as the presence of the Moscow Saint Metropolitan Peter of the Holy Tsar Vladimir, showing a panslavic integration of this part of the Serb eparchy inhabited by the oldest nobility of the area in the trend started by Peter the Great which aimed at the unification of the orthodox world and the liberation of this population from Catholic or Islamic rule. This social consciousness of the Maramuresh nobility combined with the orthodox religious consciousness is one of the last remaining remnants of the byzantine heritage of the orthodox man defined by the byzantine theology of the 8 ecumenical synods.

The case of Barsana is extraordinary because we can identify the process of integration of an already constructed elite. In Maramuresh the only family which had estates prior to the coming of the orthodox nobility was the Ujhely family, related to the Csaky nobles, who had its easternmost estate at Visk (Vishkova in Romanian). When the area of Maramuresh was populated with a series of nobles and their servants were used in fighting against the tartars and to protect the road of Radna, the Beszterecze (Bistritz) valley, and the access to central Hungry beyond Zilah, the Ujhely family became secondary in Maramuresh affairs. This shows the great prestige of the nobles of Maramuresh, of which the first of them was Staniszlo Berszan.

The detailed account of these estates erroneously called kniezates by Radu Popa ${ }^{64}$, because they were not peasant Vlach-like kniezates, but noble estates donated through property right, must take into account the presence of heraldic emblems. The presence of an open crown on the Berszan heraldic shield shows a ducal rank, the voivode position of Staniszlo Berszan, and parallelism can be made with the use of the crown in Serbian heraldry ${ }^{65}$.

In the diploma, this text is the key: Nulli ergo omnino hominum liceat presentem paginam infrigere, aut ei ausu temerario contraire, et nullus sit, qyi super populos dicte terre Zurduky collectam aliquam exigere presumpmat, quod si quis facere presumpserit, Regiam indignacionem incurrat ${ }^{66}$. This shows that the peoples of Stramtura (Zurduk) were perpetual serfs.

We can also speak about the great genealogical connections of other Maramuresh families, Man and Stoica, who gave orthodox priests and the bishops of Maramuresh (Iosif Stoica, who brought Serb jurisdiction back to Maramuresh) and were related to great families like Pereny, which were descended by the female line from the Frankopan which were related to the Brankovics and the Corvines ${ }^{67}$.

63 Teodor Baconsky, Biserici de lemn din Maramureş [Wooden Churches of Maramures], (Segovia: Ed. Artec Impresiones, 2009), 128.

${ }^{64}$ Radu Popa, Adrian Ioniță, Țara Maramureşului în veacul al XIV-lea[Land of Maramures in the fourteenth century], (Bucureşti: Ed. Enciclopedică, 1997), 34.

65 Acovic, Heraldika i Srbi, 112 and 189.

66 Roşca, Mănăstirea Barsana, 15.

${ }^{67}$ Imre Pereny, Genealogy index, last modified June 8, 2005, http://genealogy.euweb.cz/hung/perenyi3.html. 
We must take into account that there is a hypothesis that the church from Calinesti, presenting Saint Simeon and Sava painted there in the altar, was the first church of the Barsana nobiliar court ${ }^{68}$. This shows that the oldest noble family of Maramuresh, with a ducal crown in the heraldic shield, came with the cult of Simeon and Sava. Simeon is painted in the altar, exceptional for a monk, and not a hierarch, but this is explained by the noble and ethno-genealogic conscience.

It can be noted that Staniszlo Berszan and his son were supporters of Bogdan, so the cult of Saints Simeon and Sava combined with the proved support given by Dusan to Bogdan ${ }^{69}$ closes the Serb circle that is the most representative feudal concept for the early Maramuresh.

We must state that this social structure which predates the Angevine feudal institutions could not have appeared in a primitive society, either autochthonous dating before the Hungarian administration, or from a primitive Balkan territory which was mountainous and under no Bulgarian, Serbian or byzantine control. This is a feudal structure that is specific to the Serb status of nobility, which was crystallized in the Serbian states of Serbia and Bosnia after Stefan Nemanja's rule. And this structure was completely crystalized, with all the ethno social identification specific to all the nobility of Serbia, and brought to Maramuresh, after which it was dissolved to ruralisation. This is the sense of the name Sarbi for the village of Olahtotfalu. This is an ethno social name, holding testimony to an old mentality that dates back to the beginning of the crystallization of the orthodox element in Hungary. Even the term boyar, attested and used on a large scale in Maramuresh for the nobility, shows this origin. This shows an early conscience of the nobility coming from an old period.

Also we can cite the case of the Lipcsey family, which descended from the Craciun voivode of Bereg ${ }^{70}$, ally and supporter of Bogdan in the founding of Moldavia and the fight against the Angevins, with the Serb connections shown above. Although the family has branches in Kriciova and Lipcea in Transcarpathia ${ }^{71}$, Russophone and a branch in Rona, the richest, from which Simeon judge of Maramuresh county came from in $1700^{72}$, Roumanophone, the relationships of these families are all noble, with the Stoica or Tivadar families.

The same is with the Bedei and Markos families of Bedeu, now in Transcarpathia, families which have the same date of origin as the Berszan $\left(1326^{73}\right)$ and have branches Ukrainophone in Ukraine, and a Roumanophone branch, Bedeoanu, in Giulesti, re-

68 Grigore Man, Biserici de lemn din Maramures[Wooden Churches of Maramures],(Baia Mare: Proema, 2005), 95; Nuțu Roşca, Mănăstirea Bârsana, 24.

${ }^{69}$ Denis Capraroiu, "Opinii istoriografice despre unul dintre voievozii cu numele Bogdan din secolul al XIV-lea [Reviews historiographical about one of the princes named Bogdan XIV century]", Analele Universitătii din Craiova, XVI, 1-19 (2011): 27-43.

${ }^{70}$ Filipaşcu, Enciclopedia familiilor nobile maramureșene, 154.

${ }^{71}$ Ibid., 154

72 Man, Biserici de lemn din Maramureş, 296.

${ }^{73}$ Filipaşcu, Enciclopedia familiilor nobile maramureșene, 18. 
lated to the Rednik of the Giulesti family, which came from Dragos son of Gyula ${ }^{74}$. Also the families of Man $^{75}$, and Lipchey-Ilosvay (the same family ${ }^{76}$ ) and the Bedeu families Marcus or Bedej ${ }^{77}$ have an open crown in their heraldic emblem. The Marcus family has a branch in Chioar $^{78}$, which remains Roumanophone to this day although the Transcarpathia branch is Russophone.

We must see that the names of the earliest ancestors of these families are southSlavic, and this gives us a clue about the language spoken in these areas before the split between the Romanian and Russian languages, due to the ruralisation of the families in villages surrounded by Ukrainian or Romanian serfs, which imposed the language. This is why the unique phenomena of different languages spoken by the same families in villages situated up to $10 \mathrm{~km}$ in distance appear.

As Dimitrie Onciul explains, the noble family of Moldavia was said to be descendant of the Serbian despots ${ }^{79}$. The same idea appears in the Letopis of Bistrita ${ }^{80}$. So in Hungary, the term Serb is defined as Olah, and afterwards in Poland as Ruthenian. It is a testimony of the Serbo-Russian great and old unity. The boyars Tautu or Onciul of Moldova (descending from Mihail from Dorohoi, the name Mihu being frequent in Maramuresh), which came as Serbs, are considered by Hungarians as Vlachs, and then they considered themselves in the $19^{\text {th }}$ century as Ruthenians, or Russians, is testimony of being in conflict with Romanian views on their origins. A Teutu Roumanophone branch exists in Coteleu. We wrote above about the Serb Saints painted in the church they built in Balinesti and the implications of it.

The great genealogist I.C.Miclescu-Prajescu, descended from Dragomir Bealogo (Serbian name frequent in Maramuresh also, where the Dragomir family of Dragomiresti descending from Iuga brother of Bogdan the founder), said that the nobility of Moldavia has two sources: a Serb source from the west and a Russo-Lithuanian source from the east. This could be the case.

We must accept that the power of Bogdan and his successors, in subduing a vast territory like Moldavia must reside in the force of the support that Dustan, wanting a second front in his confrontation with the catholic Angevins, must have given him, as was proven at Cuhea. The financial and military Serb support explains the speed of this Moldavian centralization. After the power of Dushan declined, ties remained with the Serbs. The heraldry found in a princely tomb in Radauti shows heraldic similarities between the Lazarevic dynasty and the early Moldavian princes, the buttons

74 Ibid., 18.

${ }^{75}$ Ibid., 155.

${ }^{76}$ Ibid., 129 and 153.

77 Ibid., 164.

78 Ibid., 164.

79 Dimitrie Onciul, Opere Complete, Originile principatelor române, Tomul I [Complete Works, Origins Romanian principalities, Volume I], (Bucureşti: Fundaţia regală pentru literatură şi artă, 1946), 43.

${ }^{80}$ Ioan Bogdan, Scrieri alese[Selected Writings], (Bucureşti: Ed. Academiei Republicii Socialiste România, 1968), 382. 
found in the tomb in Radauti being identical to those on the relic of Tsar Lazar ${ }^{81}$. This heraldic identity, going to the fact that the buttons come from the same manufacturer, is yet to be investigated in its total consequences regarding the genealogy of the Maramuresh princes of Cuhea. These connections explain the force of the Pontic expansion of Moldavia.

Dushan's support imposed on the Bogdan family as a dynasty and imposed his authority over the other nobles. The prestige of Dushan's imperial declaration and idea of a Holy Dynasty in an orthodox medium imposed Bogdan as monarch, and contributed to the change of status from nobility to royalty. This is seen in the legends accrediting the ascendance of the voivodes of Moldavia from the Serb despots as we have seen. The usage of the Serb heraldic dynastical emblem shows this. A symbolic adoption of the holy monarchy of Serbia of Moldavia, mediated by the church is probably by relationships unknown to this day. The authority of the voivode resides in the support provided by the Holy dynasty of Serbia, an image with strong force in orthodoxy, regarding the nature of monarchical power connected with the idea of divine right. This may be also the sense of a heraldic coincidence, the symbolic adoption in the divine right of the monarchy by the Serb tsars to confer legitimacy to the new state and to Bogdan's family among others, including the Dragffy which opposed the process of founding Moldavia as an orthodox monarchy.

A continuation of the process of legitimization from Serbia was by the canonization of Stefan Nemanja by his son, the first crowned Prvovencani. The introduction of the name Stefan in the family of the Moldavian voivodes was done to make this connection more evident, the name Stefan being the monarchical name of the Serbian Nemanjic and Lazarevic. The representation of Simeon Nemanja, the monk-king, at Radauti, the necropolis of the Bogdan dynasty of Moldavia, shows this symbolic adoption into the holy Nemanjic dynasty. The only portrait of the same kind which can be seen is in Studenica, the symbolic Sion of the new Serbian state. Probably at the entrance of the Neamt monastery the Holy Nemanjic dynasty is represented, but the inscriptions have disappeared and only the succession of the Holy Kings remain. This link is shown in the re-establishment of the ties with the Pec Patriarchate during the Metropolitan Teoctist of Stefan the Great. This idea can be linked also to the presence of the JesseTree in both the painting in Serbia and Moldavia in royal monasteries built by the ruling dynasty. The Jesse Tree is a symbolic representation of the idea of a Holy Dynasty, a Serb concept. The tree can also be found in the iconostasis of Sarbi church, and of other Maramuresh wooden churches, and in a large form painted in the church of Desesti, a village inhabited by the Giulesti Dragos family, which also descends from Bogdan's brother Iuga, via a Gherhes marriage.

${ }^{81}$ Acovic, Heraldika i Srbi, 53; Lia Bătrîna, Adrian Bătrîna , Biserica "Sfântul Nicolae ” din Rădăuți-Cercetări arheologice şi interpretări istorice asupra inceputurilor Tării Moldovei[The church "Saint Nicholas" Rădăuți-archaeological research and historical interpretation of the beginnings of Moldavia], (Piatra Neamț: Ed. Constantin Matasă, 2012), 464. 
The names of the family of the Moldavian voivodes, Bogdan, Juga and Latko are to be found in the cadet branch of the Nemanjic, Jug Bogdan Vratko Nemanjic, the father-in-law of Lazar Hrebeljanovic, was a descendent of Vukan, son of Nemanja. Vratko is a form of Latko (Vlatzko from Vladislau, and Vladislau gives Ladislau), and Bogdan and Juga are well known names in Moldavia. Maybe a connection with this branch is the source of the heraldic coincidence.

It must be noted also that Djuradj Balsic, alleged ancestors of the Bals of Moldavia, was also son in law to Jug Bogdan. And thus the dynastical claim of the Bals in Moldavia later in history had this connection to a family considered in the genealogical imagination as to be connected to the founders of Moldavia. The Movila also had succession via a female line. One of the sons of Jug Bogdan is Vlaskoe Bogdan Damian. The term Vlaskoe shows a connection with the Romanian spaces. Should this be connected to Bogdan of Maramuresh?

In the descendants of Stefan Miroslav is found the name Peter, Nikola and Vladislav, specific also for the dynasty and family of Bogdan ${ }^{82}$, and to the early Basarab's. The name Margareta, name of a princess of Moldavia from Bogdan's family, also spelled Mushata, was found to be a daughter of Stefan Dragutin ${ }^{83}$.

Without this support, the Maramuresh relatives of the Moldavian prince became rustic (with some exceptions, like the Petrovai family, which had branches related to the Kornis and Nyary families ${ }^{84}$ ), in contrast to the relatives of the Moldavian princes, which started being considered as descendants of Serb princes, Stefan the Great being called in a venetian document king of the Serbs. ${ }^{85}$ This in a time of great Serb influence at the Court of Mathias and of the writing of the Gesta of Roman and Vlahata, which states the role of Saint Sava in the founding of Moldavia, at which we can add the painting of icons of Sava at Voronet and Balinesti. In this episode of the relationship between Dushan and his successor Urosh Nejak and Bogdan and his successor the role of the Serbian orthodox clergy must have been important.

We must note that the Angevins, trying to protect their politics in Hungary, banned the activities of the Serb priests which came with the orthodox nobility ${ }^{86}$. This shows the importance of the position of the Serb priests, who did not accept the participation of the orthodox nobility at war against the country of origin. Also the alliance between Ladislau $\mathrm{Kan}^{87}$ and the Nemanjic, through his marriage, is important in this context. This image persisted, many Moldavian and Wallachian families stating genealogies from the Serbian families of Lazarevic, Brankovic, Balsic or Obilic, till the $18^{\text {th }}$ century $^{88}$, the case of Brancoveanu who accepted a wedding in his family with the Bals

${ }^{82}$ Zorica Zlatko Nikovic, Stefan Nemanja[Stefan Nemanja], (Beograd, Grafoprint, 2013), 142.

${ }^{83}$ Ibid., 144.

${ }^{84} \mathrm{Pal}$, Cercetarea calității de nobil în comitatul Maramureş, 302.

${ }^{85}$ Alexandru Simon, Ştefan cel Mare şi Matia Corvin [Stephen the Great and Matthias Corvinus], (Cluj Napoca: Ed. Presa Universitară Clujeană, 2005), 169.

86 Pop, Din mâinile valahilor schismatici, 298-300.

${ }^{87}$ Ibid. 282.

${ }^{88}$ Cantacuzino, Genealogia Cantacuzinilor, 26. 
family being a case of Romantic genealogy applied to his times, the Bals being chosen only for this mythological ancestry, combined with the identity BrancoveanuBrankovic, encouraged by Djuradj Brankovic, the Transylvanian humanist.

The Sapanta cemetery of Maramuresh consists of iconic images of the noble people buried there, with acathist-like inscriptions. Is this a last remnant of the idea of the holy Nemanjic dynasty in this far corner of Maramuresh? As was the case of Saint Simeon and Sava icon from Calinesti, of Maramuresh?

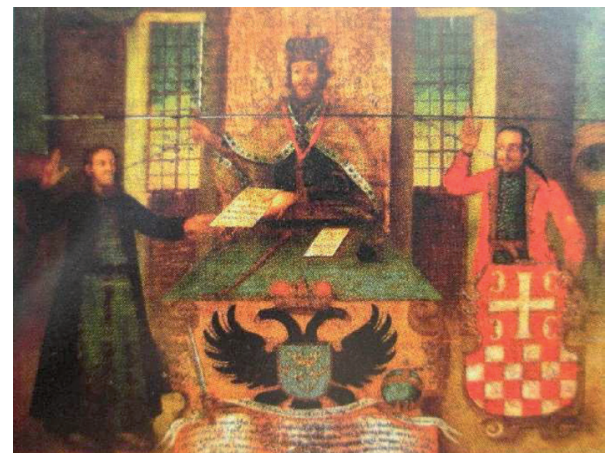

Fig. 1. Privileges for the Vlachs of Rudolf II Source: Acovic, Heraldika i Srbi, 556 (in accordance with the author).

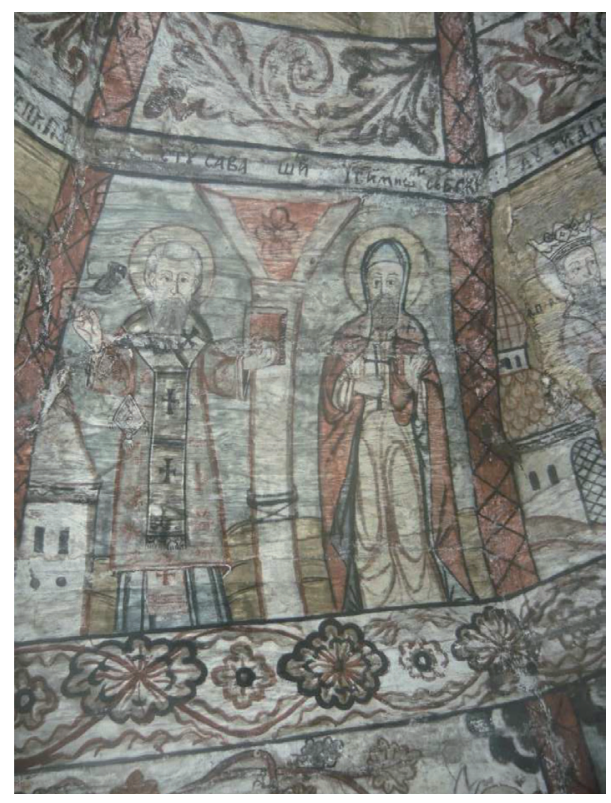

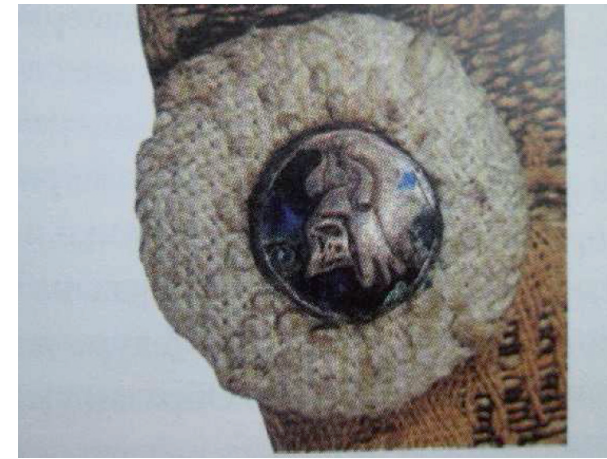

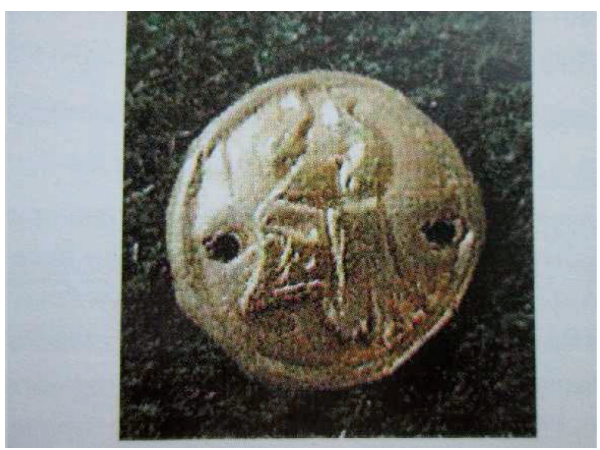

Fig. 2. The buttons of Tsar Lazar and the buttons of a voivode of Moldavia unearthed at Radauti (possibly Bogdan or Latcu)

Source: Acovic, Heraldika i Srbi, 53 (in accordance with the author).

Fig. 3. Saint Sava and Saint Simeon from Calinesti (personal photo collection) 


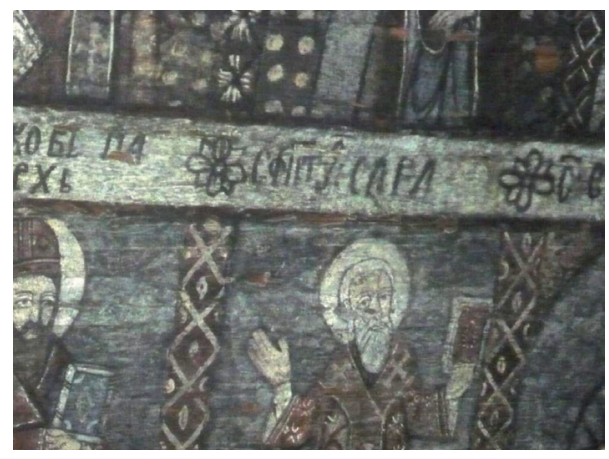

Fig. 4. Saint Sava from Ieud Church (personal photo collection)

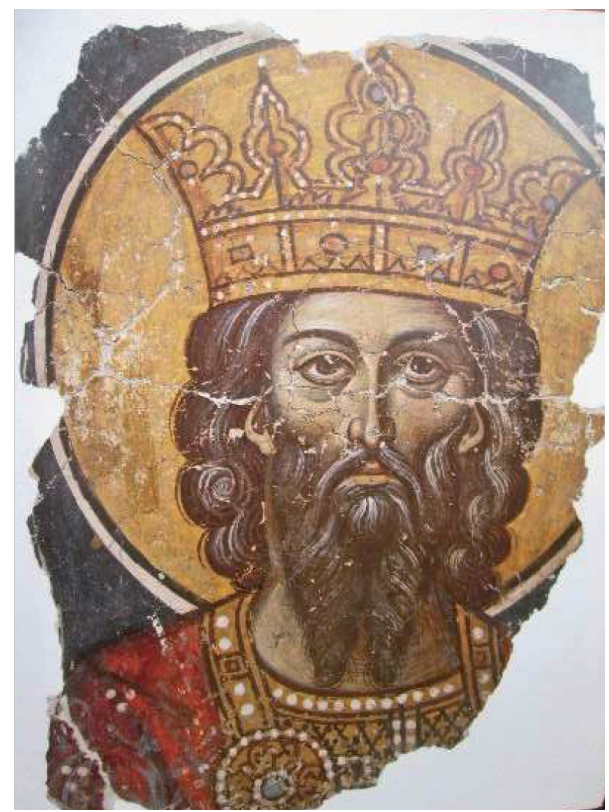

Fig. 6. Saint Tsar Lazar from Curtea de Arges Monastery

Source: Muzeul Național de Artă al României, MârturiiFrescele Mănăstirii Argeșului [Testimonials - Arges Monastery Frescoes], (Bucureşti: Muzeul de Artă al Românieie, 2012), 73.

Fig. 8. Saint Simeon (centre) from the Bogdana Monastery (personal photo collection)

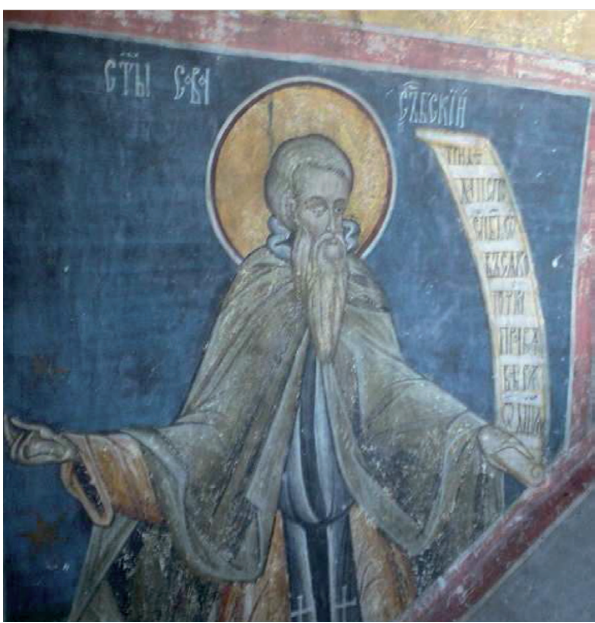

Fig. 5. Saint Sava from Balinesti Church (personal photo collection)

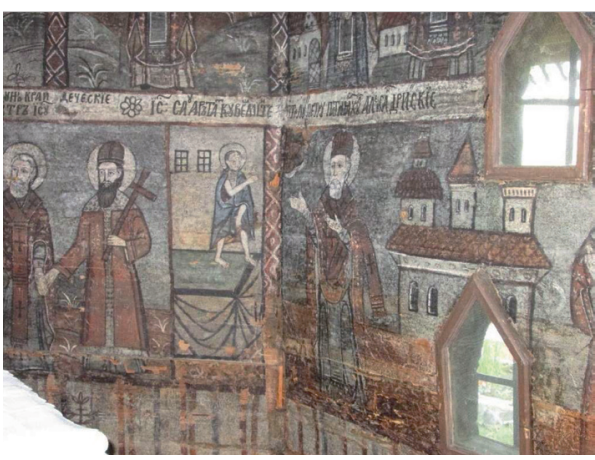

Fig. 7. Saint Stefan Decanski (in front) from Ieud Church (personal photo collection)

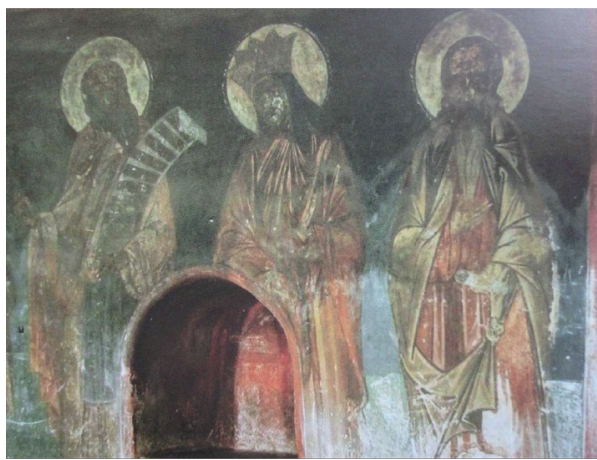


